TITLE:

\title{
Autosomal dominant moyamoya disease maps to chromosome 17q25.3(Abstract_要旨)
}

AUTHOR(S):

Mineharu, Yohei

CITATION:

Mineharu, Yohei. Autosomal dominant moyamoya disease maps to chromosome 17q25.3. 京都大学, 2008, 博士(医学)

ISSUE DATE:

2008-03-24

URL:

http://hdl.handle.net/2433/135797

RIGHT: 


\begin{tabular}{|c|c|}
\hline 氏 & 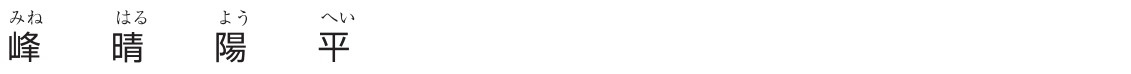 \\
\hline 学位 (専攻分野) & 士（医 \\
\hline 学位記 番号 & 医 博 第 3177 号 \\
\hline 学位授与の日付 & 平成 20 年 3 月 24 日 \\
\hline 学位授与の要件 & 学位規則第 4 条第 1 項該当 \\
\hline 研究科 · 専攻 & 医学研究科脳統御医科学系専攻 \\
\hline 学位論文題目 & $\begin{array}{l}\text { Autosomal dominant moyamoya disease maps to chromosome } 17 \mathrm{q} 25.3 \\
\text { (常染色体優性遺伝形式の家族性もやもや病は } 17 \mathrm{q} 25.3 \text { に責任遺伝子が存在す } \\
\text { る) }\end{array}$ \\
\hline
\end{tabular}

論文調查委員教主授查水章教授木原正 博 教授高橋良輔

\section{論文内容 の 要旨}

むやもや病は両側の内頝動脈終末部位が狭窄または閉塞する原因不明の疾患である。家族性むやむや病が存在することか ら、これまでいくつかの遺伝研究がなされてきたが遺伝形式は不明なままであり、信頼性の高い遺伝子座は見つかっていな W。

そこで、まず、遺伝形式を決めるために、むやもや病の発症者が 3 名以上集積する高集積家系を 15 家系収集して家系解 析を行った。全ての家系が 3 世代以上に渡っており、父一息子、父一娘、母一息子、母一娘の全ての遺伝様式が認められた。 あやあや病患者の子孫 135 名のうち、59 名（43.7\%）が患者あるいは保因者（患者 45 名、保因者 14 名）であり、家族性 あやもや病は浸透率の低い、常染色体優性遺伝形式をとると考えられた。この結果に基づき、責任遺伝子座を同定するため、 affected-member only method（罹患者のみを扱い、非罹患者のデー夕は除外する方法：浸透率の低い疾患に適用する）を 用いた、パラメトリック連鎖解析を行った。解析は全ゲノムで、マイクロサテライトマーカーを用いて行った。また、家族 性むやもや病の家系内には、もやもや病ではないが、片側性のもやもや病や、頭蓋内内頝動脈終末部位の高度狭窄を認める 人が多数認められたため、2 種類の診断基準に基づき解析を行った。1つは狭義のもやもや病で、厚生労働省のあやもや病 診断基準に基づいて、両側性のむやむや病のみを䍜患者として扱い、もう 1 つは広義のもやむや病で、狭義のもやもや病患 者に加えて、片側性のあやもや病や、頭蓋内内䅡動脈終末部位の高度狭窄を持つ者屯罹患者として扱った。その結果、いず れの解析においても、17q25.3 のみに有意な連鎖を認めた。そして、狭義の診断基準よりも、広義の診断基準を用いた方が、 より強い連鎖を認めた。ハプロタイプ解析では、1家系を除く 14 家系において、広義のもやあや病患者全員が疾患のリスク ハプロタイプを共有していた。

以上の結果から、家族性もやもや病の常染色体優性遺伝家系の主たる責任遺伝子座は $17 \mathrm{q} 25.3$ に存在することが示された。

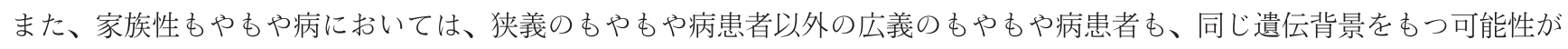
示唆された。

\section{論 文 審 査 の 結 果 の 要 旨}

あやもや病は両側の内頝動脈終末部位が狭窄または閉塞する原因不明の疾患である。家族性むやむや病が存在することか ら、これまでいくつかの遺伝研究がなされてきたが遺伝形式は不明なままであり、信頼性の高い遺伝子座は見つかっていな W。

遺伝形式を決めるために、あやあや病の発症者が 3 名以上の高集積家系を 15 家系収集して家系解析を行った。全ての家 系が 3 世代以上に渡っており、父一息子、父一娘、母一息子、母一娘の全ての遺伝様式が認められた。むやもや病患者の子 孫 135 名のうち、59 名（43.7\%）が患者あるいは保因者（患者 45 名、保因者 14 名）であり、家族性あやあや病は浸透率 の低い、常染色体優位遺伝形式をとると考えられた。この結果に基づき、パラメトリック連鎖解析を行った。また、家族性 
あやもや病の家系内には、あやもや病ではないが、片側性のもやむや病や、頭蓋内内頝動脈終末部位の高度狭窄を認める人 が多数認められたため、2 種類の診断基準に基づき解析を行った。1つは両側性のもやもや病のみを罹患者として扱い、も う 1 つは片側性のもやもや病や、頭蓋内内頝動脈終末部位の高度狭窄を持つ者も罹患者として扱った。いずれの解析におい てあ、17q25.3のみに有意な連鎖を認めた。

以上の結果から、家族性もやむや病の常染色体優性遺伝家系の主たる責任遺伝子座は $17 \mathrm{q} 25.3$ に存在することが示された。 以上の研究はもやもや病の遺伝学的背景の解明に貢献し、今後のもやもや病研究の発展に寄与することころが大きい。

したがって、本論文は博士（医学）の学位論文として価值あるあのと認める。なお本学位授与申請者は、平成 19 年 12 月 14 日実施の論文内容とそれに関連した諮問を受け、合格と認められたあのである。 